[Araştırma Makalesi / Research Article ]

\section{Kustamonu Eğitim Dergisi Kastamonu Education Journal}

Ocak 2019 Cilt:27 Sayı:1

kefdergi.kastamonu.edu.tr
Başvuru Tarihi/Received: 16.11.2017

Kabul Tarihi/Accepted: 16.04 .2018

DOI: $10.24106 /$ kefdergi.2380

\title{
İlkokul 2, 3 ve 4. Sınıf Türkçe Ders ve Çalışma Kitaplarında Yer Alan Etkinliklerin Yenilenmiş Bloom Taksonomisine Göre İncelenmesi'
}

\section{Evaluation of the Activities In the Turkish Coursebooks (Student's Books and Workbooks) Used at the 2nd, 3rd, and 4th Classes of State Primary Schools According to Revised Bloom's Taxonomy}

\section{Öz}

\author{
Hakan ULUM², Serdarhan Musa TAŞKAYA
}

Bu araştırmada Millî Eğitim Bakanlığına bağlı devlet okullarında okutulan, ilkokul 2, 3, ve 4. sınıf Türkçe ders ve çalışma kitaplarında yer alan etkinlikleri, Yenilenmiş Bloom Taksonomisi'nden yararlanarak bilgi birikimi boyutu ve bilişsel süreç boyutu açısından sınıflayıp değerlendirmek ve bu etkinliklerin, üst düzey bilişsel becerilerin gelişimine katkı sağlama potansiyeline sahip olup olmadığını, öğrencinin bilişsel gelişimine uygun bilgiler içerip içemediğini tespit etmek amaçlanmıştir. Araştırmada, nitel araştırma modelinin desenlerinden belge (doküman) incelemesi kullanıımıştır. Araştırmanın örneklemini Türkiye Cumhuriyeti'ne bağlı devlet okullarında 2016-2017 yılında okutulan ilkokul düzeyindeki 2, 3, ve 4. sınıf Türkçe ders ve öğrenci çalışma kitaplarında bulunan etkinlikler oluşturmaktadır. Örneklem grubundaki tüm etkinlikler, Yenilenmiş Bloom Taksonomisi belirtke tablosuna, araştırmacı tarafindan çeşitli kaynaklardan yararlanılarak hazırlanan bilgi boyutu ve bilişsel beceri boyutu ile ilgili anahtar tablolardan yararlanılarak yerleştirilmiştir. Elde edilen tüm verilerin, SPSS 24 (Statistical Package for the Social Sciences) istatistik programı kullanılarak frekans, yüzde, iki değişken için iki yönlü kay-kare testi hesaplanmış ve tablolaştırma yapılmıştr. Bu şekilde, araştrma kapsamında toplanan veriler, betimsel analize tâbi tutulmuştur. Araştırmadan elde edilen bulgular; Türkiye Cumhuriyeti'ne bağlı devlet okullarında 2016- 2017 yılında okutulan ilkokul düzeyindeki 2, 3, ve 4. sınıf Türkçe ders ve öğrenci çalışma kitaplarında bulunan etkinliklerin Yenilenmiş Bloom Taksonomisi'nin bilişsel beceri boyutunu oluşturan tüm basamaklarına çeşitli oranlarda dağıldığını, bilgi boyutunu oluşturan tüm gruplardan sadece ilk üç gruba dağıldığını göstermektedir. Elde edilen verilerden 2, 3, ve 4. sınıf Türkçe ders ve öğrenci çalışma kitaplarında bulunan etkinliklerin üst düzey zihinsel becerilerden ziyade daha çok alt düzey zihinsel becerileri ölçtüğü anlaşılmaktadır. Ayrıca 2, 3, ve 4. sınıf Türkçe ders ve öğrenci çalışma kitaplarında bulunan etkinliklerin, sınıf düzeyi bakımından üst düzey zihinsel beceriler ve alt düzey zihinsel becerileri ölçme potansiyeli anlamlı bir farklılık göstermemektedir. Araştırma sonuçlarına dayalı olarak getirilen bazı öneriler şunlardır: MEB tarafindan hazırlanan öğretim programları; gelişim psikolojisinin temel ilkelerini, eğitim alanında yaşanan güncel değişimleri ve bilimsel araştırmalar sonucunda ulaşılan bilgileri göz önünde bulundurmalıdır. Bu bağlamda hazırlanan ders ve çalışma kitapları amacına uygun olacaktır. Ders kitapları hazırlanırken alanında uzman kişiler, tüm dünyada benimsenen ilkeleri göz önünde tutarak, toplumun ve çağın gereğini göz ardı etmeden çalışmalıdır. Yapılan bu ve buna benzer araştırmaların sonucu; ders kitaplarındaki etkinliklerin YBT'nin boyutları açısından dengeli bir dağılım göstermediğini ortaya koymuştur. Bu araştırmaların sonuçları MEB tarafindan önemsenmeli ve bu konuda kitap hazırlama komisyonunda değerlendirilmek üzere raporlar toplatılmalıdır.

Anahtar Kelimeler: Orijinal bloom taksonomisi, yenilenmiş bloom taksonomisi, Türkçe ders ve çalışma kitapları, Türkçe dersi, ölçme ve değerlendirme.

\section{Abstract}

In this study, it was aimed to evaluate the activities in the Turkish course books (student's books and workbooks) used at the $2 \mathrm{nd}, 3 \mathrm{rd}$, and 4 th classes of state primary schools according to revised bloom taxonomy, with respect to categorising and evaluating these course books in the dimensions of knowledge accumulation and cognitive facet, and also with regard to identifying whether the activities in these course books contribute to the development of high level order cognitive skills and contain data suitable for the development of students' cognitive skills. In the

1. Bu çalışma, birinci yazarın ikinci yazar danışmalığında hazırladığı yüksek lisans tezinden üretilmiştir.

2. Çukurova Üniversitesi, Sosyal Bilimler Enstitüsü, Adana, Türkiye; https://orcid.org/0000-0002-1398-6935

3. Mersin Üniversitesi, Sınıf Öğretmenliği Anabilim Dalı, Mersin, Türkiye; https://orcid.org/0000-0003-0618-0084

Atıf / Citation: Ulum, H., \& Taşkaya, S.M. (2019). Illkokul 2, 3 ve 4. Sınıf Türkçe ders ve çalışma kitaplarında yer alan etkinliklerin yenilenmiş bloom taksonomisine göre incelenmesi. Kastamonu Education Journal, 27(1), 107-118. doi:10.24106/kefdergi.2380 
study, based on a qualitative research design, document (text) analysis was put into practice. The data of the study were gathered from the activities in the Turkish course books used at the $2 \mathrm{nd}, 3 \mathrm{rd}$, and 4 th classes of state primary schools in 2016-2017 education year. The activities in the course books were categorised based on the chart of revised Bloom's taxonomy and key tables related to the knowledge and cognitive skills dimensions formed by the researcher by means of various sources. The data of the study were analysed by means of SPSS 24 (Statistical Package for the Social Sciences) and the frequency, percentage and chi-square test were tabulated. Accordingly, the data of the study is based on descriptive analysis. The findings of the study; the activities in the Turkish course books used at the 2nd, 3rd, and 4th classes of state primary schools of Turkish Republic in 2016-2017 education year disperse at different rates in all the levels of cognitive dimension and in all dimensions of knowledge level. The findings of the study represents that the activities in the Turkish course books used at the $2 \mathrm{nd}$, 3rd, and 4th classes of state primary schools assess mostly low level cognitive skills rather than high level cognitive. Furthermore, there is no significant relationship between classes and the potential of assessing high/low order cognitive skills in the activities in the Turkish course books used at the $2 \mathrm{nd}$, $3 \mathrm{rd}$, and 4 th classes. Some suggestions based on the findings of the research are as follows: Teaching programs prepared by Ministry of National Education should take the basic principles of developmental psychology and current changes in the field of education into account, as well as the data obtained from scientific studies. The textbooks will be based on their goals within this context. As course books are being prepared, specialists in the related field should work without ignoring the needs of society and the time period, keeping the globally adopted principles of preparing textbooks. The results of this research and the similar ones showed that the activities in the textbooks did not show a balanced distribution regarding the dimensions of RBT. Besides, the results of these inquiries should be considered by Ministry of National Education and reports should be collected for the evaluation of the book preparation committee.

Keywords: Revised bloom's taxonomy, Turkish assessment and evaluation, Turkish course books. 


\section{Extended Abstract}

An effective assessment and evaluation should be conducted in order to foster productive, functional, and qualified educational activities. The assessing and evaluating function of educational tools is significant in terms of evaluating high level cognitive skills. Accordingly, it is a must to properly analyze the educational tools that are most frequently used in assessment and evaluation activities. It is also required to accurately evaluate the course books which are among the mostly used educational tools, and to question their convenience for the curriculum and education policy.

It is highly important whether the activities in the course books which constitute for the structure of the educational programs, as well as being among the most indispensable parts of educational process and a part of assessment and evaluation facets represent the principles of education perspective, the principle of providing high level cognitive skills, and the main skills. While carrying out such an evaluation, the approaches commonly approved, extensively used, and reflecting the current educational principles, should be taken into consideration. Among the categorization approaches, the most commonly used and approved one is Bloom's Taxonomy, which has been revised by some researchers to meet the requirements of the era and reflect the current educational principles.

According to Piaget, the concrete procedures involve children aged 7-11 years. The most prominent feature of this period is that children can make concrete transactions. Children in this period can reason if they are supported by concrete examples. This is an important finding for the revised bloom taxonomy.

In this study, it was aimed to evaluate the activities in the Turkish course books (student's books and workbooks) used at the $2 \mathrm{nd}$, 3rd, and 4th classes of state primary schools according to revised bloom's taxonomy, with respect to categorising and evaluating these course books in the dimensions of knowledge accumulation and cognitive facet, and also with regard of identifying whether the activities in these course books contribute to the development of high level order cognitive skills.

In response to this general aim, the following questions were answered in the research.

1. How is the distribution of activities in the $2 \mathrm{nd}, 3 \mathrm{rd}$ and 4 th grade study and workbooks of Turkish primary schools according to the knowledge accumulation dimension and cognitive process dimension of the Revised Bloom's Taxonomy?

2. How is the distribution of activities in the $2 \mathrm{nd}, 3 \mathrm{rd}$ and 4 th grade study and workbooks of Turkish primary schools according to the lower and higher cognitive skill levels of the Revised Bloom's Taxonomy?

3. Is there significance between the distribution of the lower and higher cognitive skill levels located in the Revised Bloom's Taxonomy and the level of the classes?

In the study, based on a qualitative research design, document (text) analysis was put into practice. The data of the study was gathered from the activities in the Turkish course books (student's books and workbooks) used at the $2 \mathrm{nd}, 3 \mathrm{rd}$, and 4th classes of state primary schools in 2016-2017 education year. The activities in the course books were categorised based on the chart of revised Bloom's taxonomy and key tables related to the knowledge and cognitive skills dimensions formed by the researcher by means of various sources. The data of the study was analysed by means of SPSS 24 (Statistical Package for the Social Sciences) and the frequencies and percentages were tabulated. Accordingly, the data of the study is based on descriptive analysis.

Prepared course and workbooks must comply with some criteria. These; developmental characteristics of children, measurement and evaluation criteria and cognitive taxonomy. This research shows similarities with the researches on revised taxonomy of bloom and textbooks made in the literature.

The findings of the study; the activities in the Turkish course books (student's books and workbooks) used at the $2 \mathrm{nd}, 3 \mathrm{rd}$, and 4th classes of state primary schools of Turkish Republic in 2016-2017 education year disperse at different rates in the levels of cognitive dimension (respectively; memorise, understand, apply, analysis, evaluate, create), and in three dimensions in knowledge level (respectively; factual knowledge, conceptual knowledge, operational knowledge, high level cognitive knowledge). The findings of the study represents that the activities in the Turkish course books (student's books and workbooks) used at the $2 \mathrm{nd}$, 3rd, and 4th classes of state primary schools assess mostly low level cognitive skills (remember, understand, apply) rather than high level cognitive skills (analyse, evaluate, create). Furthermore, there is no significant relationship between classes and the potential of assessing high/low order cognitive skills in the activities in the Turkish course books (student's books and workbooks) used at the $2 \mathrm{nd}, 3 \mathrm{rd}$, and 4 th classes. 


\section{Giriş}

Öğretim programlarına hizmet eden, programın ögeleri arasında bulunan ölçme ve değerlendirme ögesinin en önemli aracı olan ders ve çalışma kitaplarının, eğitimi şekillendirecek müdahalelerden ayrı tutulması söz konusu edilemez. Bu müdahalelerden birisi de öğrenci davranışlarını istendik yönde değiştirmeyi amaçlayan eğitimin, bu amaç doğrultusunda davranışların belirli özellikler altında belirli sınıflamalara tabi tutulmasıdır (Yeşilyurt, 2012).

Bloom Taksonomisi (OBT) yayımlandığı günden beri üst düzey zihinsel becerilerin faaliyete geçmesine yönelik eğitim programlarının hazırlanması ve yürütülmesinde büyük katkı sağlayan bir sınıflandırmadır (Arı, 2011; Bekdemir ve Selim, 2008; Wineburg ve Schneider, 2013). Dünya genelinde öğretim programlarının hedefleri ve ölçme değerlendirme soruları, Bloom'un Taksonomisi ile oluşturulmuş veya sınanmıştı. 1956 yılında tamamlanarak yayımlanan Bloom taksonomisi altı seviye olarak oluşturulmuştur. Uygulama dışındaki diğer ana kategoriler, alt kategorilere de bölünmüştür. İlk Bloom taksonomisinin en alt (temel) basamağında bilgi seviyesi vardır. Bu seviyeden daha zor seviyelere doğru çıktkça sırasıyla; kavrama, uygulama, analiz, sentez ve değerlendirme basamakları birbirini takip etmektedir. Bilgi, kavrama, uygulama basamakları alt bilişsel seviyeler olarak kabul edilirken; analiz, sentez, değerlendirme, üstbilişsel seviyeler olarak kabul edilir (Anderson ve Krathwohl, 2001; Bloom ve ark., 1956; Krathwohl, 2002).

Bloom Taksonomisinin geliştirilmeye başlandığı zamanlarda eğitim programları daha çok davranışçı öğrenme yaklaşımının izlerini taşımaktaydı. Daha sonra davranışçı yaklaşımın bu izleri etkisini yitirmeye başlamış ve müfredatlar yapısalı kurama dayalı, öğrenci merkezli olmuştur. 1956 yılında geliştirilen sınıflandırma yaklaşımı, yapılandırmacı yaklaşımın ön gördüğü öğrenci merkezli eğitim, ön planda olan bir aktif öğrenme, etkin bireysel katılım, öğrenenin öğrenme sorumluluğunu üstlenmesi, bilginin keşfedilip yapılandırılması gibi becerileri kendi yapısı ile bütünleştirememiştir. Bloom'un geliştirdiği sınıflandırma yaklaşımı ile yapısalcı yaklaşımın ölçülmesini istediği üst düzey zihinsel beceriler de tam anlamıyla ölçülememiştir (Amer, 2006; Anderson ve Krathwohl, 2001; Arı, 2011; Ayvacı ve Türkdoğan, 2010). Bu gelişmelerin ardından Yenilenmiş Bloom Taksonomisi (YBT) geliştirilmiştir.

Yenilenmiş Bloom Taksonomisi; öğrenciyi merkeze alan müfredatların belirttiği gibi üst düzey bilişsel becerileri kategorilere ayıracak şekilde hazırlanmış, ilk formundan daha kapsamlı, hazırlanırken evrensel bir dil kullanılmış, günümüz psikolojik intiyaçlara ve eğitim kuramlarına uygun, uygulanabilir örneklerle desteklenmiş bir formdur. Çağın gereksinimlerini karşılamadığı gerekçesi ile eleştirilere maruz kalan Bloom Taksonomisinin, Bloom’un öğrencileri tarafindan 1995 yılından itibaren yoğun çalışmalar ile revize edilmesi ile ortaya çıkmıştır (Amer, 2006; Anderson ve Krathwohl, 2014). Bloom Taksonomisinin üzerinde yapılan tüm değişiklikleri on iki maddede özetlemek mümkündür. Bu değişiklikler kendi arasında gruplara dağıtılabilir. Bu grupları; vurgulama alanında yapılan değişiklikler, terminoloji alanında yapılan değişikler, yapı alanında yapılan değişiklikler olarak üç sınıfa ayırabiliriz. Yapılan on iki temel değişikliğin dört tanesi vurgulama alanında, dört tanesi terminoloji alanında, dört tanesi yapı alanında yapılan değişiklikler olarak gruplandırılabilir (Anderson ve Krathwohl, 2014).

Tablo 1. YBT' nin Yapısı (Anderson ve Krathwohl, 2014: 131).

\begin{tabular}{|c|c|c|c|c|c|c|}
\hline \multirow{2}{*}{$\begin{array}{l}\text { Bilgi Birikimi } \\
\text { Boyutu }\end{array}$} & \multicolumn{6}{|c|}{ Bilişsel Süreç Boyutu } \\
\hline & 1.Hatılama & 2.Anlama & 3.Uygulama & 4.Çözümleme & 5.Değerlendirme & 6.Yaratma \\
\hline A. Olgusal Bilgi & - & - & - & - & - & - \\
\hline B. Kavramsal Bilgi & - & - & - & - & - & - \\
\hline C. İşlemsel Bilgi & - & - & - & - & - & - \\
\hline D. Üstbilişsel Bilgi & - & - & - & - & - & - \\
\hline
\end{tabular}

Uzun yıllardır eğitimde ve özellikle program geliştirme alanında etkisi süregelen Bloom Taksonomisi, zaman geçtikçe gelişmiş ve değişmiştir. Yenilenmiş Bloom Taksonomisi, ders programları hazırlanırken, uygulamada ve ölçme değerlendirmede göz önüne alınmalıdır. Bu nedenle en yaygın olarak kullanılan ders aracı olan ders kitaplarının YBT'ye uygunluğunun incelenerek uygun olup olmadığı ortaya koyulmalıdır.

\section{Araştırmanın Amacı}

Araştırmanın amacı, illkokul 2, 3 ve 4. sınıf, Türkçe ders ve çalışma kitaplarında (TDÇK) yer alan etkinlikler YBT'de bulunan bilgi birikimi boyutu ve bilişsel süreç boyutu basamaklarına göre nasıl dağılım gösterdiğini ortaya koymaktır.

\section{Araştırmanın problemi}

1. İlkokul 2, 3 ve 4. sınıf TDÇK'de yer alan etkinliklerin YBT'de bulunan bilgi birikimi boyutu ve bilişsel süreç boyutu basamaklarına göre dağılımı nasıldır? 
2. Illkokul 2, 3 ve 4. sınıf TDÇK'de yer alan etkinliklerin YBT'de bulunan alt düzey bilişsel beceri basamakları ile üst düzey bilişsel beceri basamakları arasında dağılımı nasıldır?

3. illkokul 2, 3 ve 4. sınıf TDÇK'de yer alan etkinliklerin YBT'de bulunan alt düzey bilişsel beceri basamakları ile üst düzey bilişsel beceri basamakları arasındaki dağılımı, sınıf seviyesine göre anlamlı farklılık göstermekte midir?

\section{Yöntem}

Araştırmada, nitel araştırma modelinin desenlerinden belge (doküman) incelemesi kullanılmıştır. Doküman incelemesi ile olguyu yansıtan belgelerin (araştırmaya kaynaklık eden) incelenmesi ile verilere ulaşılması hedeflenmiştir.

\section{Çalışma Grubu}

Nitel çalışmalar genelde kasıtlı bir biçimde belirlenmiş küçük örneklemlerle yürütülür. Amaçlı bir şekilde örneklem belirlenmesindeki mantkk, araştırmanın daha derinlemesine yapılmasına olanak sağlayarak bilgi zenginliği içeren durumlar oluşturmaktır. Bilgi bakımından zengin durumları çalışmak araştırmaya deneysel genellemelerden ziyade derinlemesine anlam yüklenmesini sağlar (Patton, 2014). Bu araştırmanın örneklemi belirlenirken bu durum göz önüne alınmıştır. Araştırmanın amacı doğrultusunda, bilgi zenginliği içeren örneklem seçmek için ders kitapları ve çalışma kitapları önemli görülmüştür. Bu araştırmanın evrenini, Türkiye'de ilkokullarda okutulan TDÇK'de bulunan etkinlikler oluşturmaktadır. Araştırmanın çalışma grubunu (örneklemini) ise devlet okullarında 2016- 2017 yılında okutulan devlet okullarında 2, 3 ve 4. sınıf TDÇK'de bulunan etkinlikler oluşturmaktadır.

Araştırmanın çalışma grubunu belirlerken nitel araştırmalarda kullanılan amaçlı örnekleme yöntemlerinden tipik durum örneklemesi kullanılmıştır. Yıldırım ve Şimşek'e (2013) göre tipik durum örneklemesinde bir yeniliğin veya yeni oluşturulmuş bir uygulamanın gözler önüne serilip tanıtımı yapılması amacıyla yeniliğin veya uygulamanın etki ettiği bir durum arasından en ilişkili olanının seçimi söz konusudur. Buradaki amaç tipik durumları çalışma grubu alarak evren hakkında genel bir kanıya varmak değil, belirli bir konu ile ilgili bilgi sahibi olmak ve bu yeterince bilgi sahibi olmayanları aydınlatmaktır.

2, 3 ve 4. sınıf TDÇK' ler bu araştırma kapsamına alınmış, ancak 1. sınıf TDÇK'de bulunan etkinlikler ilk okuma yazma öğretimi kapsamında, genellikle harflerin kavratılmasına yönelik olması nedeniyle çalışmaya dâhil edilmemiştir. Aşağıda, Tablo 2'de araştırmanın çalışma grubunun sınıflara göre dağılımı verilmektedir.

Tablo 2. 2016-2017 Eğitim Öğretim Yılı illkokul TDÇK'de Yer Alan Etkinlik Sayıları

\begin{tabular}{lc}
\hline Kitap & Etkinlik SayıSı \\
\hline ilköğretim 2. Sınıf TDÇK 1, 2 ve 3. Kitap & 172 \\
ilköğretim 3. Sınıf TDÇK 1, 2 ve 3. Kitap & 165 \\
Illköğretim 4. Sınıf TDÇK 1, 2 ve 3. Kitap & 238 \\
Toplam & 575 \\
\hline
\end{tabular}

\section{Verilerin Toplanması}

Etkinliklerin YBT Belirtke Tablosuna uygun ve doğru bir şekilde yerleştirilmesi için iki adet anahtar tablo hazırlanmıştir.

İlk anahtar tablo, etkinliklerin YBT'nin bilgi boyutuna yönelik YBT Belirtke Tablosuna yerleştirilmesini kolaylaşttrıp, doğruluğunu arttrmak amacı ile oluşturulmuştur. Durmuş Ali Özçelik tarafindan çevrilen Anders ve Krathwohl'ün (2014) editörlüğünde hazırlanan “Öğrenme Öğretim ve Değerlendirme ile İlgili Bir Sınıflama Bloom'un Eğitimin Hedefleri İle illgili Sınıflamasının Güncelleştirilmiş Biçimi" kitabında bulunan "YBT Belirtke Tablosu", 2, 3 ve 4. sınıf TDÇK'de bulunan etkinliklerin tabloda gösterilmesine uygun düşecek biçimde şekil yönünden düzenlenmiştir.

İkinci anahtar tablo ise, etkinliklerin YBT'nin bilişsel süreç boyutuna yönelik YBT Belirtke Tablosuna yerleştirilmesini kolaylaştırıp, doğruluğunu arttırmak amacı ile oluşturulmuştur. Öncelikle Bloom ve arkadaşlar (1956) tarafindan kitap gözden geçirililerek ön bilgiler toplanmıştır. Ardından Durmuş Ali Özçelik tarafindan çevrilen "Öğrenme Öğretim ve Değerlendirme ile İlgili Bir Sınıflama Bloom'un Eğitimin Hedefleri Ille İlgili Sınıflamasının Güncelleştirilmiş Biçimi” kitabı ve YBT'nin editörlerinde David R. Krathwohl'un 2002 yılında yayınladığı "A Revision of Bloom's Taxonomy: An Overview" makalesi detaylı olarak incelenmiştir. Bu üç temel kaynak anahtar tablonun bilişsel beceri boyutunu oluşturması açısından temel görülmüştür.

Veriler toplanırken Durmuş Ali Özçelik tarafından çevrilen “Öğrenme Öğretim ve Değerlendirme ile İlgili Bir Sınıf- 
lama Bloom'un Eğitimin Hedefleri Ille İlgili Sınıflamasının Güncelleştirilmiş Biçimi” kitabında bulunan "Bilişsel Süreç Boyutu" tablosunun ana gruplara ait başlıklara ait açıklamalar daha anlaşılır bir hale getirilmiştir. Sonrasında detaylı bir kaynak taraması ile bilişsel süreç boyutunun ana kategorilerine ait beceriler, bir eylem belirtecek şekilde tabloya yerleştirilmiştir. Bu becerilerin asıl olarak nitelemek istediği eylemleri Türkçeye çevirirken İngilizceden İngilizceye sözlük kullanılmıştr. Böylece ana kategorilerin asıl olarak belirtmek istediği eylemlerden sapmalar en aza indirilmeye çalışlmıştir. Sonrasında tabloda, etkinliklerin YBT'nin bilişsel süreç boyutuna yönelik YBT Belirtke Tablosuna yerleştirilmesini kolaylaştırıp, doğruluğunu arttırmak için (yine belirtilen kaynaklar esas alınarak) soru kökleri oluşturulmuştur. Böylece etkinlikler YBT Belirtke Tablosunda bilişsel süreç boyutuna göre uygun yerlere yerleştirilirken, sınıflandırılmada kolaylaştıııı, doğrulayıcı ve çabuklaştırıcı bir anahtar tablo sağlanmıştır.

Ayrıca veri toplama araçlarının geçerliği için biri Eğitim Programları ve Öğretimi, biri İngiliz Dili ve Eğitimi, biri Mütercim ve Tercümanlık alanından olmak üzere üç akademisyenden uzmandan görüş alınmıştır.

\section{Verilerin Analizi}

Yıldırım ve Şimşek'e (2013) göre betimsel analiz yönteminde, araştırma kapsamında toplanan verilerin, önceden saptanmış temalara göre özünün yansıtılması ve yorumlarda bulunulması söz konusudur. Bu doğrultuda araştırma kapsamında toplanan veriler, betimsel analize tabi tutulmuştur.

\section{Bulgular ve Yorumlar}

Tablo 3. İlkokul 2. sınıf TDÇK'de yer alan etkinliklerin YBT'de bulunan bilgi birikimi boyutu ve bilişsel süreç boyutu basamaklarına dağılımı.

\begin{tabular}{lcccc}
\hline \multirow{2}{*}{ 2. Sınıf } & \multicolumn{2}{c}{$f$} & \multirow{2}{*}{ Toplam } & $\%$ \\
\cline { 2 - 3 } & Olgusal & Kavramsal & & \\
\hline Hatırlama & 59 & 10 & 69 & 40,1 \\
Anlama & 56 & 0 & 56 & 32,6 \\
Uygulama & 12 & 7 & 19 & 11 \\
Çözümleme & 1 & 0 & 1 & 0,6 \\
Değerlendirme & 11 & 0 & 11 & 6,4 \\
Yaratma & 1 & 15 & 16 & 9,3 \\
Toplam & 140 & 32 & 172 & 100 \\
\hline
\end{tabular}

2. sınıf düzeyindeki TDÇK, YBT'nin bilgi birikimi boyutu açısından incelendiğinde; 172 etkinliğin, bilgi birikimi boyutlarından (olgusal bilgi, kavramsal bilgi, işlemsel bilgi, üstbilişsel bilgi) sadece olgusal bilgi ve kavramsal bilgi grubunda bulunan etkinlikler olduğu görülmektedir. 2. sınıf düzeyindeki Türkçe Ders ve Öğrenci Çalışma Kitaplarında bulunan 172 etkinliğin 140'। $(\% 81,4)$ olgusal bilgi birikimi, 32'si $(\% 18,6)$ ise kavramsal bilgi grubuna dâhildir.

2. sınıf düzeyindeki TDÇK, YBT'nin bilişsel beceri boyutu açısından incelendiğinde; 172 etkinliğin bilişsel beceri boyutu açısından (hatırlama, anlama, uygulama, çözümleme, değerlendirme, yaratma) her bir basamağa, farklı oranlarda dâhil olduğu görülmektedir. 2. sınıf düzeyindeki TDÇK 'de bulunan 172 etkinliğin 69'u (\%40) hatrlama, 56'sı $(\% 32,6)$ anlama, 19'u (\%11) uygulama, 1'i $(\% 0,6)$ çözümleme, 11'i $(\% 6,4)$ değerlendirme ve 16 'sı $(\% 9,3)$ yaratma basamağı kapsamında olan etkinliklerdir.

Tablo 4. illkokul 3. sınıf TDÇK'de yer alan etkinliklerin YBT'de bulunan bilgi birikimi boyutu ve bilişsel süreç boyutu basamaklarına dağılımı.

\begin{tabular}{|c|c|c|c|c|c|}
\hline \multirow{2}{*}{ 3. Sinıf } & \multicolumn{3}{|c|}{$f$} & \multirow{2}{*}{ Toplam } & \multirow{2}{*}{$\%$} \\
\hline & Olgusal & Kavramsal & İşlemsel & & \\
\hline Hatırlama & 51 & 6 & 0 & 57 & 34,5 \\
\hline Anlama & 41 & 2 & 1 & 44 & 26,7 \\
\hline Uygulama & 5 & 8 & 1 & 14 & 8,5 \\
\hline Çözümleme & 3 & 0 & 1 & 4 & 2,4 \\
\hline Değerlendirme & 23 & 2 & 1 & 26 & 15,8 \\
\hline Yaratma & 3 & 17 & 0 & 20 & 12,1 \\
\hline Toplam & 126 & 35 & 4 & 165 & 100 \\
\hline
\end{tabular}

| Kastamonu Eğitim Dergisi, 27(1), 2019| 
3. sınıf düzeyindeki TDÇK, YBT'nin bilgi birikimi boyutu açısından incelendiğinde; 165 etkinliğin bilgi birikimi boyutlarından (olgusal bilgi, kavramsal bilgi, işlemsel bilgi, üstbilişsel bilgi) sadece olgusal bilgi, kavramsal bilgi ve işlemsel bilgi grubunda bulunan etkinlikler olduğu görülmektedir. 3. sınıf düzeyindeki TDÇK'de bulunan 165 etkinliğin 126'sı $(\% 76,4)$ olgusal bilgi birikimi, 35'i $(\% 21,2)$ kavramsal bilgi, 4'ü $(\% 2,4)$ ise işlemsel bilgi grubuna dâhildir.

3. sınıf düzeyindeki TDÇK, YBT’nin bilişsel beceri boyutu açısından incelendiğinde; 165 etkinliğin bilişsel beceri boyutu açısından (hatırlama, anlama, uygulama, çözümleme, değerlendirme, yaratma) her bir basamağa, farklı oranlarda dâhil olduğu görülmektedir. 3. sınıf düzeyindeki Türkçe Ders ve Öğrenci Çalışma Kitaplarında bulunan 165 etkinliğin 57'si (\%34,5) hatrlama, 44'ü $(\% 26,7)$ anlama, 14'ü $(\% 8,5)$ uygulama, 4'ü $(\% 2,4)$ çözümleme, 26'sı $(\% 15,8)$ değerlendirme ve 20 'si $(\% 12,1)$ yaratma basamağı kapsamında olan etkinliklerdir.

Tablo 5. illkokul 4. sınıf TDÇK'de yer alan etkinliklerin YBT'de bulunan bilgi birikimi boyutu ve bilişsel süreç boyutu basamaklarına dağılımı.

\begin{tabular}{lcccc}
\hline \multirow{2}{*}{ 4. Sınıf } & \multicolumn{3}{c}{$f$} & \multirow{2}{*}{ Toplam } \\
\cline { 2 - 3 } & Olgusal & Kavramsal & & \\
\hline Hatırlama & 62 & 14 & 76 & 31,9 \\
Anlama & 73 & 17 & 90 & 37,8 \\
Uygulama & 13 & 7 & 20 & 8,4 \\
Çözümleme & 5 & 4 & 9 & 3,8 \\
Değerlendirme & 11 & 0 & 11 & 4,6 \\
Yaratma & 6 & 26 & 32 & 13,4 \\
Toplam & 170 & 68 & 238 & 100 \\
\hline
\end{tabular}

4. sınıf düzeyindeki TDÇK, YBT'nin bilgi birikimi boyutu açısından incelendiğinde; 238 etkinliğin bilgi birikimi boyutlarından (olgusal bilgi, kavramsal bilgi, işlemsel bilgi, üstbilişsel bilgi) sadece olgusal bilgi ve kavramsal bilgi grubunda bulunan etkinlikler olduğu görülmektedir. İlkokul 4. sınıf düzeyindeki TDÇK'de bulunan 238 etkinliğin 170'i $(\% 71,4)$ olgusal bilgi birikimi grubuna, 68'i $(\% 28,6)$ ise kavramsal bilgi grubuna dâhildir.

4. sınıf düzeyindeki TDÇK, YBT'nin bilişsel beceri boyutu açısından incelendiğinde; 238 etkinliğin bilişsel beceri boyutu açısından (hatırlama, anlama, uygulama, çözümleme, değerlendirme, yaratma) her bir basamağa, farklı oranlarda dâhil olduğu görülmektedir. 4. sınıf düzeyindeki TDÇK'de bulunan 238 etkinliğin 76'sı (\%31,9) hatrlama, 90'ı (\%37,8) anlama, 20'si $(\% 8,4)$ uygulama, 9'u $(\% 3,8)$ çözümleme, 11'i $(\% 4,6)$ değerlendirme ve 32'si $(\% 13,4)$ yaratma basamağına dâhildir.

Tablo 6. illkokul 2. sınıf TDÇK'de yer alan etkinliklerin YBT'de bulunan alt düzey bilişsel beceri basamakları ile üst düzey bilişsel beceri basamaklarına dağılımı.

\begin{tabular}{llccc}
\hline 2. Sınıf & & f & Toplam & $\%$ \\
\hline \multirow{2}{*}{$\begin{array}{l}\text { Alt düzey bilişsel } \\
\text { beceri basamakları }\end{array}$} & Anlama & 69 & & \\
& Uygulama & 56 & 144 & 83,7 \\
\hline \multirow{2}{*}{$\begin{array}{l}\text { Üst düzey bilişsel } \\
\text { beceri basamakları }\end{array}$} & Çözümleme & 19 & & \\
& Değerlendirme & 11 & 28 & 16,3 \\
& Yaratma & 16 & & \\
\hline Toplam & & & 172 & 100 \\
\hline
\end{tabular}

2. sınıf düzeyindeki TDÇK'de bulunan etkinlikler, YBT'nin bilişsel beceri boyutunun, alt düzey bilişsel beceri basamakları ile üst düzey bilişsel beceri basamakları açısından incelendiğinde; 172 etkinliğin 144 'ünün $(\% 83,7)$ alt düzey bilişsel beceri basamakları ile ilgili olduğu, $28^{\prime}$ inin ise $(\% 16,3)$ üst düzey bilişsel beceri basamakları ile ilgili olduğu görülmektedir.

Tablo 7. İlkokul 3. sınıf TDÇK'de yer alan etkinliklerin YBT'de bulunan alt düzey bilişsel beceri basamakları ile üst düzey bilişsel beceri basamaklarına dağılımı.

\begin{tabular}{llccc}
\hline 3. Sınıf & & f & Toplam & $\%$ \\
\hline \multirow{2}{*}{ Alt düzey bilişsel } & Hatırlama & 57 & & \\
beceri basamakları & Anlama & 44 & 15 & 69,7 \\
& Uygulama & 14 & & \\
\hline
\end{tabular}




\begin{tabular}{llccc}
\hline 3. Sınıf & f & Toplam & $\%$ \\
\hline Üst düzey bilişsel & Çözümleme & 4 & & \\
beceri basamakları & $\begin{array}{l}\text { Değerlendirme } \\
\text { Yaratma }\end{array}$ & 26 & 50 & 30,3 \\
\hline Toplam & 20 & & 172 & 100 \\
\hline
\end{tabular}

3. sınıf düzeyindeki TDÇK'de bulunan etkinlikler, YBT'nin bilişsel beceri boyutunun, alt düzey bilişsel beceri basamakları ile üst düzey bilişsel beceri basamakları açısından incelendiğinde; 165 etkinliğin $115^{\prime}$ inin $(\% 69,7)$ alt düzey bilişsel beceri basamakları ile ilgili olduğu, 50'sinin $(\% 30,3)$ üst düzey bilişsel beceri basamakları ile ilgili olduğu görülmektedir.

Tablo 8. İlkokul 4. sınıf TDÇK'de yer alan etkinliklerin YBT'de bulunan alt düzey bilişsel beceri basamaklar ile üst düzey bilişsel beceri basamaklarına dağılımı.

\begin{tabular}{llccc}
\hline 4. Sınıf & & $f$ & Toplam & $\%$ \\
\hline \multirow{2}{*}{$\begin{array}{l}\text { Alt düzey bilişsel } \\
\text { beceri basamakları }\end{array}$} & Anlamama & 76 & & \\
& Uygulama & 90 & 186 & 78,2 \\
\hline \multirow{2}{*}{$\begin{array}{l}\text { Üst düzey bilişsel } \\
\text { beceri basamakları }\end{array}$} & $\begin{array}{l}\text { Çömleme } \\
\text { Değerlendirme }\end{array}$ & 9 & & \\
& Yaratma & 32 & 52 & 16,3 \\
\hline Toplam & & & 238 & 100 \\
\hline
\end{tabular}

4. sınıf düzeyindeki TDÇK'de bulunan etkinlikler, YBT'nin bilişsel beceri boyutunun, alt düzey bilişsel beceri basamakları (hatırlama, anlama, uygulama) ile üst düzey bilişsel beceri basamakları (çözümleme, değerlendirme, yaratma) açısından incelendiğinde; 238 etkinliğin 186'sı $(\% 78,2)$ alt düzey bilişsel beceri basamakları ile ilgili olduğu, 52'sinin $(\% 21,8)$ üst düzey bilişsel beceri basamakları ile ilgili olduğu görülmektedir.

Tablo 9. illkokul 2, 3 ve 4. sınıf TDÇK'de yer alan etkinliklerin YBT'de bulunan alt düzey bilişsel beceri basamakları ile üst düzey bilişsel beceri basamakları arasındaki dağııımının, sınıf seviyesine göre farklılı̆ı.

\begin{tabular}{|c|c|c|c|c|c|c|c|}
\hline \multirow{2}{*}{$\begin{array}{l}\text { Değişkenler } \\
\text { Düzey }\end{array}$} & & \multicolumn{3}{|c|}{ Sinıf } & \multirow{2}{*}{ Toplam } & \multirow{2}{*}{$x$} & \multirow{2}{*}{$p$} \\
\hline & & 2. Sinıf & 3.Sinıf & 4. Sinıf & & & \\
\hline \multirow{2}{*}{$\begin{array}{l}\text { Alt düzey bilişsel } \\
\text { beceri basamakları }\end{array}$} & $\mathrm{N}$ & 144 & 115 & 186 & 445 & \multirow{6}{*}{9,60} & \multirow{6}{*}{0,08} \\
\hline & $\%$ & 83,7 & 69,7 & 78,2 & 77,4 & & \\
\hline \multirow{2}{*}{$\begin{array}{l}\text { Üst düzey bilişsel } \\
\text { beceri basamakları }\end{array}$} & $N$ & 28 & 50 & 52 & 130 & & \\
\hline & $\%$ & 16,3 & 30,3 & 21,8 & 22,6 & & \\
\hline \multirow{2}{*}{ Toplam } & $N$ & 172 & 165 & 238 & 575 & & \\
\hline & $\%$ & 100 & 100 & 100 & 100 & & \\
\hline
\end{tabular}

TDÇK'de bulunan etkinliklerin, YBT'nin bilişsel beceri boyutunun, alt düzey bilişsel beceri basamakları (hatırlama, anlama, uygulama) ile üst düzey bilişsel beceri basamakları (çözümleme, değerlendirme, yaratma) açısından farklııı gösterip göstermediği ya da sınıf seviyesi ile ilişkili olup olmadığına ilişkin kay-kare testi sonuçları tablo 9' da verilmiştir. Bu tablo incelendiğinde 2, 3 ve 4. sınıf düzeyindeki TDÇK'de bulunan etkinliklerin bulunduğu kitapların sınıf seviyeleri ile bu kitaplarda bulunan etkinliklerin YBT'nin bilişsel süreç boyutunda bulunan düzeyler (alt düzey zihinsel becerileri veya üst düzey zihinsel beceriler) arasında bir ilişki olup olmadığını belirlemek için yapılan iki değişken için iki yönlü kay-kare testi sonucuna göre sınıf düzeyi ile etkinlik düzeyi (alt düzey-üst düzey) arasında anlamlı bir ilişki yoktur. $(X 2(2)=9,60$, $p>0,05)$. 


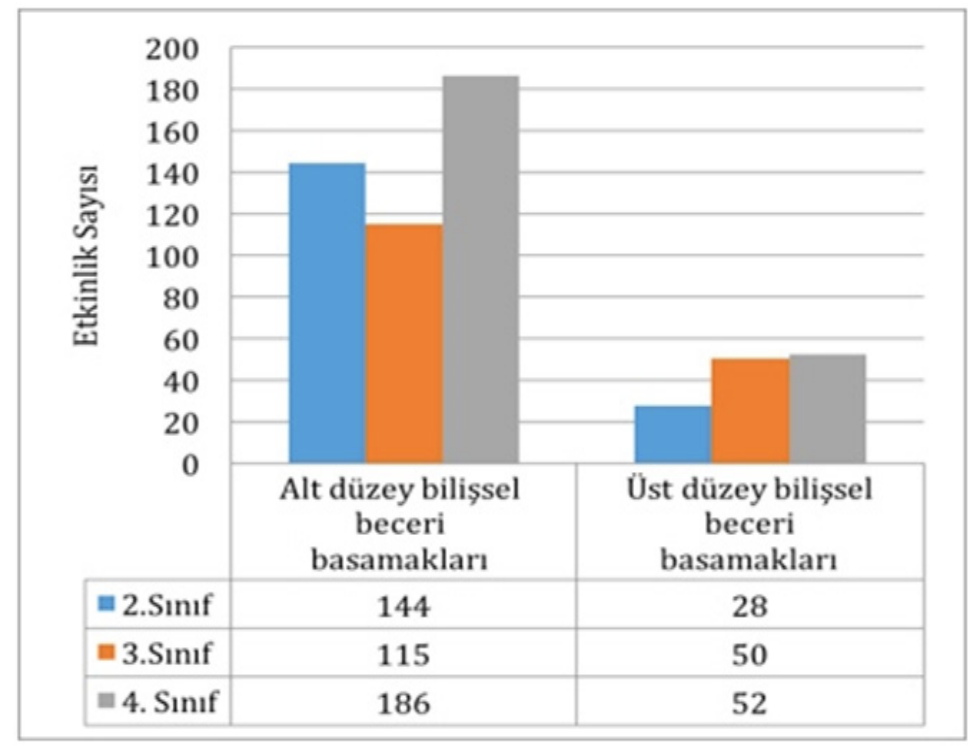

Şekil 1. TDÇK'de yer alan etkinliklerin YBT'de bulunan alt düzey bilişsel beceri basamakları ile üst düzey bilişsel beceri basamakları arasındaki dağııımının, sınıf seviyesine göre farklılığı.

\section{Tartışma ve Sonuç}

Piaget (1953), somut işlemler döneminin çocuklarda ortalama 7-11 yaşları arasını kapsadığını savunmuştur. Bu dönemin en belirgin özelliği çocukların somut işlemler yapabilmesidir. Bu dönem çocukları mantıklı ve somut örneklerle desteklenebilir olduğu sürece muhakeme yapabilirler. Çocuklar 11 yaşından sonra somut işlem döneminden soyut işlem dönemine geçerler. Soyut işlemler dönemindeki çocukların muhakeme yapabilmesi için problemi somut olarak görmesi gerekmez.

YBT'nin bilgi birikimi boyutunda gruplar arasında derinlemesine giden bir aşamalılık söz konusudur; olgusal bilgi grubunda bir konu alanındaki temel somut bilginin ezberlenmesi söz konusu iken, kavramsal bilgi de bu bilgi parçacıkları arasındaki ilişki ile ilgili daha derinlere ulaşma çabası görülür. Bu iki bilgi grubu da "ne" sorusunun cevabını ararken işlemsel bilgi grubunda ise "nası" sorusunun cevabı aranır. Burada sadece somut bilgi parçalarının hatırlanmasından ziyade daha soyut bir durum (somut bilgi parçalarının kullanımı) söz konusudur. Üstbilişsel bilgi ise tamamen biliş ile ilgilidir. Burada tam anlamı ile soyutlama söz konusudur. Öğrenci kendi bilgileri ve düşüncelerinden sorumludur (Anderson ve Krathwohl, 2014).

Türkiye'de 66 ayını dolduran çocuklar ilkokula kayıt edilir. Somut işlemler dönemindeki 7- 11 yaş grubundaki çocuklar ilkokulda öğrenim görmektedirler. Araştırmanın amacı doğrultusunda incelenen, ilkokullarda okutulan Türkçe ders kitaplarının somut işlemler dönemindeki çocuklara uygun bilgi barındıran kaynaklar olması yerinde olacaktı. Henüz soyut işlem döneminde olmayan ilkokul çocuklarının soyut bilgiler barındıran üstbilişsel bilgi grubuna dâhil kaynak kitaplar kullanmasının etkisi araştıılmalıdır. İlkokullarda okutulan kitapların daha çok somut bilgiler barındırması (olgusal ve kavramsal bilgi grubuna dâhil) beklenmektedir.

Bunun yanında öğretim programlarının temel taşlarından, öğrenme ve öğretme faaliyetlerinin önemli bir unsuru olan ölçme ve değerlendirme ögesinin, en önemli uygulama araçları arasında olan ders ve çalışma kitapları kapsamındaki etkinliklerin, eğitim ilkelerinden; temel becerilerin yanında üst düzey zihinsel becerileri de kazandırma ilkesini barındırıp barındırmadığı çok önemlidir. Türkçe Öğretim Programının asıl amacı, Türkçenin anadil olarak doğru, etkili ve kurallarına uygun kullanılması olmakla birlikte; düşünme, anlama, sıralama, sınıflama, sorgulama, ilişki kurma, eleştirme, tahmin etme, analiz-sentez yapma, değerlendirme gibi zihinsel becerilerin geliştirilmesidir. Bu becerilerin büyük çoğunluğu üst düzey zihinsel beceriler kapsamı altındadır.

YBT'nin bilişsel süreç boyutu; bazı konu alanlarının içerdiklerinin ne dereceye kadar öğrenilmiş olması ve belli bir süre kalıcı olabilmesinden ziyade öğrenilenlerin kalıcılığı ve transferi üzerinde durmaktadır (Anderson ve Krathwohl, 2014). Bilişsel süreç boyutu sadece alt düzey zihinsel becerilerden oluşmaz, üst düzey zihinsel beceriler üzerine vurgu yapar. Bu açıdan bakıldığında Türkçe Öğretim Programının asıl amacı ile örtüşmektedir. İlkokullarda okutulan TDÇK'de bulunan etkinliklerin alt düzey zihinsel becerilerin yanında dengeli bir şekilde üst düzey zihinsel becerileri de ölçmesi beklenir. 
Türkçe öğretim Programının amaçlarına ve YBT’nin temel ilkelerine bakıldığı zaman; araştırmadan elde edilen bulgulara dayanılarak; 2, 3 ve 4. sınıf TDÇK'de yer alan öğretim etkinliklerinin somut bilgiler içeren bilgi birikimi grubuna (olgusal ve kavramsal bilgi) dâhil olması ve bilişsel beceri boyutu açısından alt düzey ve üst düzey zihinsel beceri basamaklarına dengeli bir şekilde dağılması beklenir.

Araştırmadan elde edilen bulgular neticesinde, 2, 3 ve 4. sınıf TDÇK'de yer alan etkinlikler; YBT'nin bilişsel beceri boyutunu oluşturan tüm basamaklarına çeşitli oranlarda dağıldığı görülmektedir. Bilgi boyutunu oluşturan tüm gruplardan (sırasıyla; olgusal bilgi, kavramsal bilgi, işlemsel bilgi, üstbilişsel bilgi) 2 ve 4. sınıf TDÇK'de yer alan etkinlikler sadece ilk iki gruba (olgusal bilgi, kavramsal bilgi) dağılırken 3. Sınıf TDÇK' de yer alan etkinlikler üç gruba (olgusal bilgi, kavramsal bilgi, işlemsel bilgi) dağılım göstermektedir. 2, 3 ve 4. sınıf düzeyindeki TDÇK'de bulunan etkinlikler, YBT'nin bilişsel beceri boyutunun, alt düzey bilişsel beceri basamakları (hatırlama, anlama, uygulama) ile üst düzey bilişsel beceri basamakları (çözümleme, değerlendirme, yaratma) göz önüne alınarak analiz edildiğinde; etkinliklerin büyük oranda alt düzey bilişsel becerileri ölçtüğü anlaşılmaktadır.

Türkçe Öğretim Programının amaçları ve YBT'nin temel ilkeleri göz önünde tutularak; 2 ve 4. sınıf TDÇK'de yer alan etkinliklerin somut bilgiler içeren bilgi birikimi grubuna (olgusal ve kavramsal bilgi) dâhil olması ve bilişsel beceri boyutu açısından alt düzey ve üst düzey zihinsel beceri basamaklarına dengeli bir şekilde dağılması beklentisi, araştırmadan elde edilen bulgular ile karşılaştırıldığında etkinliklerin somut bilgiler içeren bilgi birikimi grubuna (olgusal ve kavramsal bilgi) dağıldığı, ancak; kavramsal bilgi grubundan ziyade büyük oranda olgusal bilgi grubuna dâhil olduğu, soyut bilgiler içeren işlemsel ve üstbilişsel bilgi grubuna dâhil etkinlik olmadığı, 3. sınıf TDÇK'de yer alan etkinliklerin ise kısmen soyut bilgiler içeren işlemsel bilgi grubuna dâhil etkinlikler olduğu ancak; işlemsel ve kavramsal bilgi grubundan ziyade büyük oranda olgusal bilgi grubuna dâhil olduğu, soyut bilgiler içeren üstbilişsel bilgi grubuna dâhil etkinlik olmadığı sonucuna ulaşılmıştır. Bunun yanında 2, 3 ve 4. sınıf TDÇK'de yer alan etkinliklerin etkinlikler bilişsel beceri boyutunun tüm basamaklarına çeşitli oranlarda dağılmasına rağmen, alt düzey zihinsel beceri basamakları ve üst düzey zihinsel beceri basamaklarına dengeli bir şekilde dağılmadığı; etkinliklerin üst düzey zihinsel beceri basamaklarından ziyade alt düzey zihinsel beceri basamaklarına dağıldığı sonucuna ulaşılmıştır.

2, 3 ve 4. sınıf TDÇK'de yer alan etkinliklerin sınıf düzeyi bakımından YBT'de bulunan, üst düzey zihinsel beceriler ve alt düzey zihinsel becerileri ölçme potansiyeli anlamlı bir farklılık göstermemektedir. Türkçe Öğretim Programının amaçlarına ve YBT'nin temel ilkelerine bakıldığı zaman; araştırmadan elde edilen bulgulara dayanılarak öğretim etkinliklerinin somut bilgiler içeren bilgi birikimi grubuna (olgusal ve kavramsal bilgi) dâhil olması, bilişsel beceri boyutu açısından alt düzey ve üst düzey zihinsel beceri basamaklarına dengeli bir şekilde dağılması beklentisi tüm sınıf düzeylerinde oluşan bir beklentidir. Bu bakımdan TDÇK' ler tüm sınıf düzeylerinde bilgi birikimi boyutunun beklentilerini karşılayarak genellikle olgusal ve kavramsal bilgi gruplarında yoğunlaşmıştır. Fakat üst düzey zihinsel becerileri ölçme bakımından tüm sınıf düzeylerinde yetersiz kalmış ve alt düzey zihinsel beceri gereken etkinliklerde yoğunlaşmıştır.

2, 3 ve 4. sınıf TDÇK'de yer alan etkinlikler sıklıkla alt düzey zihinsel becerileri ölçmektedir. Bu bakımdan TDÇK'de bulunan etkinlikler öğrencileri ezbere yönlendirebilecek türde etkinlikler olduğu söylenebilir. Öğrencileri oluşturmaya, eleştirmeye, değerlendirmeye vb. karmaşık zihinsel süreçlere yönelten etkinlik sayısı azdır. Akyol (2001) tarafindan yapılan araştırmada, ilköğretim okulları 5. sınıf Türkçe kitaplarındaki okuma metinleriyle ilgili soruların analizi yapılmış ve okuma metinleriyle ilgili soruları; soruluş amaçlarına, hazırlanış şekillerine (klasik, essey, vb.) ve cevap kaynaklarına (metin içi, metin dışı ve metinler arası) göre analiz edilmiştir. Araştırma verileri, soruların büyük bir çoğunluğunun öğrencileri ezbere yönlendirdiği, değerlendirme, sonucu tahmin etme gibi düşünme ve yargılamayı gerektiren sorulara ya hiç yer verilmediğini ya da oldukça az yer verildiğini göstermiştir.

Yapılan bu çalışma sonucunda tüm sınıf düzeyindeki kitaplardaki etkinlikler, YBT’nin bilişsel süreç boyutundaki basamaklara homojen bir şekilde dağılım göstermezken (etkinlikler alt düzey basamaklarda yoğunlaşmıştır); YBT’nin bilgi birikimi boyutunda bulunan gruplara, öğrencinin gelişim düzeyine (somut işlemler döneminde bulunan 2, 3 ve 4. sınıf öğrencileri) uygun şekilde (ilk iki grupta yoğunlaşmıştır) dağılım göstermiştir. Savaş (2014) tarafindan, ortaokul Türkçe ders kitaplarındaki dinleme etkinliklerinin Yenilenmiş Bloom Taksonomisinde yer alan bilişsel beceri basamaklarına dağılımını belirleme amacı ile yapılan araştırma sonucunda; dağılımda belirgin bir düzensizlik ve belli basamaklarda (özellikle alt düzey olanlarda) yoğunlaşma olduğu sonucuna ulaşılmıştır. Çevik (2010) tarafindan yapılan çalışmada MEB tarafindan hazırlanan, 2000-2008 yıllarında okutulan 9, 10 ve 11. sınıf fizik ders kitaplarında yer alan soruların incelenmiş, üç kitapta bulunan toplam 1227 soru çözümlenmiştir. Çözümleme sonuçlarına göre; kitaplarda bulunan 1227 sorunun \%87'si alt düzey bilişsel beceri gerektiren bilgi, kavrama ve uygulama basamağına ait sorulardan oluşurken, soruların \%13'ü ise üst düzey bilişsel beceri gerektiren analiz, sentez ve değerlendirme basamaklarına ait olduğu saptanmıştır. Kahramanoğlu (2013), çalışmasında 6., 7. ve 8. sınıf fen dersinde kullanılan ders kitaplarındaki ünite sonu 
değerlendirme sorularının alt düzey düşünme becerilerini ölçtüğü sonucuna ulaşmıştr.

Güfta ve Zorbaz (2008) yaptıkları çalışmada ilköğretim ikinci kademe Türkçe derslerinde kullanılan yazılı sınav sorularının genel olarak düzeyleri ile bu sorular içerisinde okuduğunu anlama, dil bilgisi ve yazılı anlatım sorularının düzeyleri belirlenmeye çalışılmıştır. Sorular içerik çözümlemesiyle, OBT'ye bilişsel alanına göre tasnif edilmiştir. Araştırma sonuçlarına göre Türkçe dersi yazılı sınavlarında, bu araştırmaya benzer şekilde büyük oranda alt bilişsel düzeylerde soru sorulduğu tespit edilmiştir.

Araştırma sonuçlarına dayalı olarak aşağıdaki öneriler getirilmiştir.

Öğretmenlere;

1. Öğretmenler; eğitim alanındaki güncel gelişmeleri takip etmeli, taksonomi üzerinde yapılan güncellemelerin (bilgi birikimi ve bilişsel beceriler boyutu) öğretimdeki rolü hakkında kendisini geliştirmeli ve duyarlılık sahibi olup; öğretim etkinliklerini (Türkçe kitaplarındaki etkinlikler haricindeki) bu yönde düzenleyerek en fazla verimi almaya gayret etmelidir. Böylece ders kitaplarındaki eksikliklerin giderilmesi sağlanacaktır.

MEB'e;

1. MEB tarafindan hazırlanan öğretim programları; gelişim psikolojisinin temel ilkelerini ve eğitim alanında yaşanan güncel değişimleri, bilimsel araştırmalar sonucunda ulaşılan bilgileri göz önünde bulundurmalıdır. Bu bağlamda Türkçe Öğretim Programlarının ışığında şekillenecek olan TDÇK'deki etkinlikler amacına uygun olacaktır.

2. Türkçe Öğretim Programlarının temel ilkeleri, kullanım alanı en geniş olan TDÇK'ye tamamen yansıtılmalıdır.

3. TDÇK hazırlanırken alanında uzman (gelişim psikolojisi, eğitim, tasarım vb.) kişiler ön planda olmalıdır. Ayrıca TDÇK'nin hazırlanması sürecinde öğretmenler sürecin her aşamasında çalışmaya dâhil edilmelidir.

4. Tüm dünyada yaygın olarak kullanılan ders kitaplarının hazırlanma ilkeleri göz önünde tutularak, toplumun ve çağın gereğini karşılayacak, Türkçe dilinin inceliklerini barındıran ders ve çalışma kitapları hazırlanmalıdır.

5. YBT alanında yapılan bilimsel çalışmalar MEB tarafindan toplanıp, derlenip, düzenlenip bir süzgeç oluşturabilir; TDÇK bu süzgeçten geçirilerek yıllık güncellemeye tabi tutulabilir.

6. Yapılan bu ve buna benzer araşttrmaların sonucu; TDÇK'deki etkinliklerin YBT'nin boyutları açısından dengeli bir dağılım göstermediğini ortaya koymuştur. Bu araştırmaların sonuçları MEB tarafindan önemsenmeli ve bu konuda kitap hazırlama komisyonunda değerlendirilmek üzere raporlar toplatılmalıdır.

Araştırmacılara;

1. İlkokul 2, 3, ve 4. sınıf TDÇK'de bulunan etkinliklerin YBT'nin bilgi boyutu ve bilişsel beceri boyutu açısından incelendiği bu araştrrmada tema sonu ölçme ve değerlendirme etkinliklerine, öğretmenlerin hazırladığı veya diğer kaynaklardan edindiği etkinliklere yer verilmemiştir. TDÇK'de bulunan etkinliklerin bilgi birikimi boyutu ve bilişsel beceri boyutu açısından eksikliklerini giderme ve tamamlayıcı olması bakımından tema sonu ölçme ve değerlendirme etkinliklerinin, öğretmenlerin hazırladığı veya diğer kaynaklardan edindiği etkinliklerin bilgi birikimi boyutu ve bilişsel beceri boyutu açısından tespit edilmesine yönelik bir bilimsel araştırma alana katkı sağlayacaktır.

2. Öğretim etkinliklerinde kullanılan herhangi bir ölçme değerlendirme aracının bilgi boyutu bilişsel beceri basamakları açısından dengeli bir dağılım içerisinde düzenlenip düzenlenmediği önemli bir konudur. Böyle bir düzenlemenin var olup olmadığının tespitini amaçlayan yıllık bilimsel araştırmalar yapılabilir.

\section{Kaynakça}

Akyol, H. (2001). İlköğretim okulları 5. sınıf Türkçe kitaplarındaki okuma metinleriyle ilgili soruların analizi. Kuram ve Uygulamada Eğitim Yönetimi, 7(2), 169-178.

Amer, A. (2006). Reflections on Bloom's revised taxonomy. Electronic Journal of Research in Educational Psychology, 4(1), 213-230.

Anderson, L. W. \& Krathwohl, D. R. (Eds.) (2001). A Taxonomy for learning teaching and assessing. a revision of Bloom's taxonomy of educational objectives. New York: Longman.

Anderson, L. W. \& Krathwohl, D. R. (Eds.) (2014). Öğrenme öğretim ve değerlendirme ile ilgili bir sınıflama: Bloom'un eğitimin hedefleri ile ilgili sınıflamasının güncelleştirilmiş biçimi. (D. A. Özçelik, Çev.) (2. Baskı). Ankara: Pegem Akademi Yayıncılık.

Arı, A. (2011). Bloom ' un gözden geçirilmiş bilişsel alan taksonomisinin Türkiye' de ve uluslararası alanda kabul görme durumu. Kuram ve Uygulamada Eğitim Bilimleri, 11(2), 749-772.

Ayvacı, H. Ş. \& Türkdoğan, A. (2010).Yeniden yapılandııılan Bloom taksonomisine göre fen ve teknoloji dersi yazılı sorularının incelenmesi. Türk Fen Eğitimi Dergisi, 7(1), 13-25. 
Bekdemir, M. \& Selim, Y. (2008). Revize edilmiş Bloom taksonomisi ve cebir öğrenme alanı örneğinde uygulaması. Erzincan Eğitim Fakültesi Dergisi, 10(2), 185-196.

Bloom, B. S., Engelhart, M. D., Furst, E. J., Hill, W. H. \& Krathwohl, D. R. (1956). Taxonomy of educational objectives: The classification of educational goals. Handbook I: Cognitive Domain. (B. S. Bloom, Ed.). New York: McKay.

Çevik, Ş. (2010). Ortaöğretim 9., 10. ve 11. sınıf fizik ders kitaplarında bulunan sorular ile 2000-2008 yılları arasında öğrenci seçme ve yerleştirme sınavlarında sorulan fizik sorularının Bloom taksonomisi açısından incelenmesi ve karşılaştırılması. Dicle Üniversitesi, Diyarbakır.

Güfta, H. \& Zorbaz, Z. K. (2008). Illköğretim ikinci kademe Türkçe dersi yazılı sınav sorularının düzeyleri üzerine bir değerlendirme. Çukurova Üniversitesi Sosyal Bilimler Enstitüsü Dergisi, 17(2), 205-218.

Kahramanoğlu, E. (2013). Illköğretim fen ve teknoloji ders kitaplarının Bloom taksonomisi açısından değerlendirilmesi. İstanbul Üniversitesi, İstanbul. Krathwohl, D. R. (2002). A Revision of Bloom's taxonomy: an overview. Theory Into Practice, 41(4), 212-218.

Patton, M. Q. (2014). Nitel Araşttrma ve Değerlendirme Yöntemleri. (M. Bütün \& S. D. Beşir, Trans.) (3. Baskı). Ankara: Pegem Akademi.

Piaget, J. (1953). The origins of intelligence in children. Journal of Consulting Psychology, 17(6), 467-467.

Savaş, Ö. (2014). Ortaokul Türkçe ders kitaplarındaki dinleme etkinliklerinin güncelleştirilmiş Bloom sınıflaması'na göre üst düzey bilişsel beceriler açısından değerlendirilmesi. Abant İzzet Baysal Üniversitesi, Bolu.

Wineburg, S. \& Schneider, J. (2013). Was Bloom's taxonomy pointed in the wrong direction? Bloom taksonomisi yanlış yönü mü işaret etti? Turkish History Education Journal, 2(2), 228-239.

Yeşilyurt, E. (2012). Öğretmen adaylarının bilişsel alanla ilgili sınama durumu soruları yazma yeterliklerinin değerlendirilmesi. Kastamonu Eğitim Dergisi, 20(2), 519-530.

Yıldırım, A. \& Şimşek, H. (2013). Sosyal bilimlerde nitel araştırma yöntemleri (9. Baskı). Ankara: Seçkin Yayıncılık. 